\title{
Influence of herbicides applied postharvest in wheat stubble on control, fecundity, and progeny fitness of Kochia scoparia in the US Great Plains
}

\author{
Authors: Vipan Kumar \& Prashant Jha
}

NOTICE: this is the author's version of a work that was accepted for publication in Crop Protection. Changes resulting from the publishing process, such as peer review, editing, corrections, structural formatting, and other quality control mechanisms may not be reflected in this document. Changes may have been made to this work since it was submitted for publication. A definitive version was subsequently published in Crop Protection, [VOL\# 71, (May 2015)] DOI\# 10.1016/j.cropro.2015.02.016

Kumar, Vipan, and Prashant Jha. "Influence of herbicides applied postharvest in wheat stubble on control, fecundity, and progeny fitness of Kochia scoparia in the US Great Plains." Crop Protection 71 (May 2015): 144-149. DOI:10.1016/j.cropro.2015.02.016. 


\title{
Influence of herbicides applied postharvest in wheat stubble on control, fecundity, and progeny fitness of Kochia scoparia in the US Great Plains
}

\author{
Vipan Kumar, Prashant Jha
}

Montana State University, Southern Agricultural Research Center, Huntley, MT 59037, USA

\begin{abstract}
Field, greenhouse, and laboratory experiments were conducted at the Montana State University Southern Agricultural Research Center, Huntley, MT, USA, in 2012 and 2013, to evaluate the effectiveness of various postharvest-applied herbicides on late-season control, fecundity, seed viability, and progeny fitness of Kochia scoparia (kochia) in wheat stubble. Paraquat + atrazine, paraquat + linuron, and paraquat + metribuzin applied at the early bloom stage were the most effective postharvest treatments for late-season control (100\%) at $28 \mathrm{~d}$ after treatment (DAT), biomass reduction (70-73\%), and seed prevention of $K$. scoparia, and did not differ from glyphosate, glufosinate, saflufenacil + 2, 4-D, saflufenacil + atrazine, tembotrione + atrazine, or topramezone + atrazine treatments. Dicamba alone, dicamba $+2,4-\mathrm{D}$, or diflufenzopyr + dicamba $+2,4-$ $\mathrm{D}$ applied at the early bloom stage were ineffective, with $<70 \%$ late-season control, $<45 \%$ biomass reduction, and $<55 \%$ seed reduction of $K$. scoparia. In the absence of a postharvest herbicide, uncontrolled kochia plants at a density of $8-10$ plants $\mathrm{m}^{-2}$ contributed $>100,000$ seeds $\mathrm{m}^{-2}$. Addition of atrazine to dicamba improved late-season control (80\%) and seed reduction (78\%) compared to dicamba alone, and reduced seed viability and 100-seed weight. There was no significant effect of any of the dicamba-containing herbicides applied at the early bloom stage on $K$. scoparia progeny fitness, including height, width, primary branches, and shoot dry weight of seedlings at $42 \mathrm{~d}$ after planting (DAP). The effective postharvest-applied herbicides investigated in this research should be utilized to prevent late-season $K$. scoparia seed bank replenishment in wheat, and as a component of herbicide resistance management program for the containment of glyphosate- and/or acetolactate synthase (ALS)-inhibitor-resistant $K$. scoparia in wheat-based crop rotations in the US Great Plains.
\end{abstract}

\section{Introduction}

Kochia scoparia (L.) Schrad. (kochia) is one of the most problematic summer annual broadleaf weeds in irrigated and dryland cropping systems of the U. S. Great Plains (Eberlein and Fore, 1984; Forcella, 1985; Wicks et al., 1994). The invasiveness of $\mathrm{K}$. scoparia is attributed to its early seedling emergence (Schwinghamer and Van Acker, 2008), rapid growth rate with $\mathrm{C}_{4}$ photosynthetic pathway (Christoffoleti et al., 1997; Friesen et al., 2009), heat and salt tolerance (Friesen et al., 2009), high fecundity $\left(>50,000\right.$ seeds plant $^{-1}$ ) ( Stallings et al., 1995), and long-distance seed dispersal by wind-mediated tumble mechanism (Baker et al., 2010; Friesen et al., 2009). In late autumn, a fully-matured K. scoparia plant breaks off at the base of the stem (absission layer) near the soil surface and tumbles with the prevailing wind, dispersing seeds across the landscape (Baker et al., 2010)
Furthermore, it exhibits wide genetic diversity due to its protogynous nature of flowering with a high degree of out-crossing and pollen-mediated gene flow (Mengistu and Messersmith, 2002; Stallings et al., 1995). K. scoparia has been reported to cause yield reductions as high as $95 \%$ in agronomic crops grown in the region, including wheat (Dahl et al., 1982; Durgan et al., 1990; Weatherspoon and Schweizer, 1971; Wicks et al., 1993, 1994).

K. scoparia has evolved resistance to several herbicide modes of action including photosystem II (PS II) inhibitors (atrazine), acetolactate synthase (ALS) inhibitors (sulfonylurea and imidazolinone herbicides), and synthetic auxins (dicamba and fluroxypyr) in the northern and central Great Plains of US (Cranston et al., 2001; Heap, 2014; Preston et al., 2009; Primiani et al., 1990). In 2007, K. scoparia 
populations resistant to glyphosate were first detected in Kansas, US (Heap, 2014; Waite et al., 2013). Since then, glyphosate-resistant $K$. scoparia has been reported in six other states in this region and in two provinces of Canada (Beckie et al., 2013; Heap, 2014; Kumar et al., 2014). In 2013, K. scoparia populations with 4.6- to 11-fold levels of resistance to glyphosate have been confirmed in chemical-fallow (chemical-fallow and wheat rotation) fields in Hill, Liberty, and Toole Counties of Montana (Kumar et al., 2014). The increased occurrence of glyphosate-resistant $K$. scoparia is a potential threat to glyphosate-resistant cropping systems, and to notill chemical fallow-based crop rotations common in this region.

Major crop rotations in the semi-arid dryland region of the U.S. Great Plains include wheat-chemical fallow, wheat-corn/grain sorghum-chemical fallow, and/or wheat-summer crop-chemical fallow (Anderson and Nielsen, 1996), where K. scoparia poses a serious problem. $K$. scoparia has an extended period of emergence (Dille et al., 2012), with cohorts emerging as early as April through late June/early July in wheat or in chemical-fallow systems (Anderson and Nielsen, 1996). Cohorts that escape early-season POST herbicide application(s) or late-emerging cohorts in wheat often remain in vegetative stage at the time of wheat maturity, and hinder mechanical harvest. Moreover, these cohorts cause substantial late-season replenishment of the soil seed bank (Mickelson et al., 2004). It has been reported that $K$. scoparia plants after decapitation at wheat harvest can regrow, and produce up to 5710 seeds plant $^{-1}$ by late autumn (Mickelson et al., 2004). It is to be noted that late-season weed escapes are more problematic in wheat due to reliance on total POST programs with a lack of effective soil residual herbicides.

Late-season or postharvest herbicide treatments are often targeted at the early bloom stage or initiation of seed set to reduce/ prevent late-season weed seed rain and seed bank increase (Bennett and Shaw, 2000; Jha and Norsworthy, 2012; Mickelson et al., 2004). Reported in other weed species such as Amaranthus palmeri L. Wats., glufosinate $\left(0.820 \mathrm{~kg} \mathrm{ha}^{-1}\right), 2$, 4-D (1.06 $\left.\mathrm{kg} \mathrm{ha}^{-1}\right)$, or dicamba $\left(0.280 \mathrm{~kg} \mathrm{ha}^{-1}\right)$ applied at the inflorescence initiation stage reduced seed production of treated plants by $95 \%$, and seed viability by $39-51 \%$ (Jha and Norsworthy, 2012). A single lateseason application of glyphosate, 2, 4-D, dicamba, or glufosinate in Chenopodium album L., Amaranthus retroflexus L., Abutilon theophrasti Medik., and Senna obtusifolia L. reduced seed production up to 99\% (Biniak and Aldrich, 1986; Fawcett and Slife, 1978; Taylor and Oliver, 1997).

Seed production from late-season weed escapes can favor the evolution of herbicide resistance due to the likelihood of resistant individuals being present in those weed escapes (Bagavathiannan and Norsworthy, 2012). Late-season herbicide applications in postharvest wheat stubble would serve as an additional tool for growers to manage glyphosate-resistant $K$. scoparia weed escapes and seed bank additions. Although a study on postharvest $K$. scoparia management has previously been conducted, only a few POST herbicides (glyphosate, 2, 4-D amine, and paraquat) were tested (Mickelson et al., 2004). Additionally, the information on the effect of postharvest-applied (late-season) herbicides on $K$. scoparia seed viability and progeny seedling fitness is lacking. The information generated from this research can be potentially utilized by growers to manage herbicide-resistant $K$. scoparia seed bank in wheat-chemical fallow, wheat-corn/grain sorghum-chemical fallow, or wheatsoyabean-chemical fallow rotations in this region. The objectives of this research were (1) to evaluate effective herbicide programs applied postharvest in wheat stubble on $K$. scoparia control and biomass reduction, and (2) to determine their impact on $K$. scoparia seed production, 100-seed weight, seed viability, and progeny seedling fitness.

\section{Materials and methods}

\subsection{Field experiments}

Field experiments ( $\left.45^{\circ} 54^{\prime} 50.11 \mathrm{~N}, 108^{\circ} 14^{\prime} 53.99 \mathrm{~W}\right)$ were conducted at the Montana State University (MSU) Southern Agricultural Research Center (SARC) near Huntley, MT, USA, in 2012 and 2013, to evaluate the effectiveness of herbicides (labeled in crops grown in rotation with wheat including corn, grain sorghum, soyabean, and/or chemical-fallow) applied postharvest in wheat stubble for $K$. scoparia control. The soil type at the study site was a Fort Collins clay loam (fine-loamy, mixed, superactive, mesic Aridic Haplustalfs) with organic matter content of $2.8 \%$ and $\mathrm{pH}$ of 7.8 . The experimental site was under no-till dryland wheat-fallow rotation prior to the initiation of the study. During late autumn of 2012 and 2013, fully-matured $K$. scoparia seeds were collected from a naturally infested area at the MSU-SARC research farm. The weed population was known to be susceptible to all herbicides tested in this study. The seeds were broadcasted in early spring prior to the spring wheat planting to obtain uniform $K$. scoparia densities in the test plots. Spring wheat variety 'Vida' $\left(70 \mathrm{~kg} \mathrm{ha}^{-1}\right)$ was planted with a no-till drill at a row spacing of 15-18 cm on April 10, 2012 and April 6, 2013, respectively. The test plots were established under dryland wheat production, with no supplemental irrigation, and fertilized with Nitrogen-Phosphorus-Potash as per the MSU recommendations for spring wheat production (Jacobson et al., 2005). Wheat was harvested with a plot-combine leaving approximately 30-35 cm tall wheat stubble on August 14, 2012 and August 12, 2013. Postharvest herbicide programs and their application rates are summarized in Table 1 . A nontreated control was included for comparison. Herbicide treatments were applied using a handheld $\mathrm{CO}_{2}$-pressurized backpack boom sprayer equipped with flat-fan nozzles (TeeJet 8001XR, Spraying Systems Co., P.O. Box 7900, Wheaton, IL), calibrated to deliver $94 \mathrm{~L} \mathrm{ha}^{-1}$ of spray solution at $276 \mathrm{kPa}$. All treatments were applied 2-3 wk following harvest of the wheat crop, when decapitated $K$. scoparia plants had noticeable regrowth, and were at the early bloom stage $(45-50 \mathrm{~cm}$ tall). Herbicide treatments were applied on September 3, 2012 and September 7, 2013.

The treatments were arranged in a randomized complete block design, with four replications. Each experimental plot was $5 \mathrm{~m}$ long by $2 \mathrm{~m}$ wide. $K$. scoparia control was visually assessed at 7,14, and $28 \mathrm{~d}$ after treatment (DAT) on a scale of $0-100 \%$ (where 0 equals no control and 100 equals complete control/plant death). Visual assessments for percent control were based on general chlorosis or necrosis of treated compared to nontreated plants. At 28 DAT, plants from a $1-\mathrm{m}^{2}$ quadrat at the center of each plot were harvested at the soil level. The inflorescence was removed from the plant by shaking with hand, and the remaining plant sample was oven-dried at $60{ }^{\circ} \mathrm{C}$ for $3 \mathrm{~d}$ to determine plant dry weight, calculated as a percentage of the nontreated control. Seeds were manually separated from the inflorescence; the coarse debris was removed using a $2-\mathrm{mm}$ mesh size sieve, and the small debris was removed with an air-propelled column blower. Weight of a sample of 100 seeds, total seed weight $\mathrm{m}^{-2}$, and number of seeds $\mathrm{m}^{-2}$ were determined. Seed production from the treated plots was calculated as a percentage of reduction from the nontreated control.

\subsection{Seed viability}

A 100-seed subsample was randomly selected from each plot sample of $K$. scoparia. Seeds were placed on double layers of filter paper (Whatman ${ }^{\circledR}$, Grade 2, Sigma-Aldrich Inc., St. Louis, MO 63178, USA) moistened with $10 \mathrm{ml}$ deionized water in $10-\mathrm{cm}$-diam petri dishes (Sigma-Aldrich). Experiments were conducted in a 
Table 1

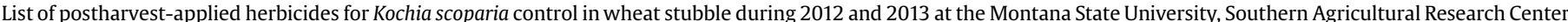
near Huntley, MT, USA.

\begin{tabular}{|c|c|c|c|}
\hline \multirow[t]{2}{*}{ Herbicide(s) } & Application rate(s) & \multirow[t]{2}{*}{ Trade name } & \multirow[t]{2}{*}{ Manufacturer } \\
\hline & $\mathrm{kg} \mathrm{ha}^{-1}$ & & \\
\hline Dicamba & 0.56 ae & Rifle & Loveland Products Inc. \\
\hline Dicamba + 2,4-D & 0.56 ae +0.56 ae & Rifle + Weedar 64 & Loveland Products Inc. and Nufarm, Inc. \\
\hline Dicamba + atrazine & $0.56 \mathrm{ae}+0.56 \mathrm{ai}$ & Rifle + AAtrex & Loveland Products Inc. and Syngenta Crop Protection \\
\hline Dicamba + glyphosate & 0.56 ae +1.26 ae & Rifle + Roundup WeatherMax & Loveland Products Inc. and Monsanto Company \\
\hline Diflufenzopyr + dicamba $+2,4-\mathrm{D}$ & $0.06 \mathrm{ai}+0.15 \mathrm{ae}+0.56 \mathrm{ae}$ & Rifle + Distinct + Weedar 64 & BASF Corporation and Nufarm, Inc. \\
\hline Glyphosate & 1.26 ae & Roundup WeatherMax & Monsanto Company \\
\hline Glufosinate & 0.59 ai & Liberty & Bayer Crop Science \\
\hline Paraquat & 0.84 ai & Gramoxone Inteon & Syngenta Crop Protection \\
\hline Paraquat + atrazine & $0.84 \mathrm{ai}+0.56 \mathrm{ai}$ & Gramoxone Inteon + AAtrex & Syngenta Crop Protection \\
\hline Paraquat + linuron & $0.84 \mathrm{ai}+0.84 \mathrm{ai}$ & Gramoxone Inteon + Linex & Syngenta Crop Protection \\
\hline Paraquat + metribuzin & $0.84 \mathrm{ai}+0.84$ ai & Gramoxone Inteon + Sencor 75DF & Syngenta Crop Protection and Bayer Crop Science \\
\hline Saflufenacil + atrazine & $0.05 \mathrm{ai}+0.56$ ai & Sharpen + AAtrex & BASF Corporation and Syngenta Crop Protection \\
\hline Saflufenacil $+2,4-D$ & $0.05 \mathrm{ai}+0.56 \mathrm{ai}$ & Sharpen + Weedar 64 & BASF Corporation and Nufarm, Inc. \\
\hline Tembotrione + atrazine & $0.09 \mathrm{ai}+0.56 \mathrm{ai}$ & Laudis + AAtrex & Bayer Crop Science and Syngenta Crop Protection \\
\hline Topramezone + atrazine & $0.02 \mathrm{ai}+0.56$ ai & Impact + AAtrex & Amvac Chemical Corporation and Syngenta Crop Protection \\
\hline
\end{tabular}

completely randomized design with four replications (25 seeds per petri dish), and repeated. Petri dishes were placed in the dark in an incubator (VMR International, Sheldon Manufacturing Inc., Cornelius, OR 97113, USA) at a constant temperature of $24^{\circ} \mathrm{C}$, which is considered optimum for seed germination of $K$. scoparia (AlAhmadi and Kafi, 2007). Light is not required for K. scoparia seed germination (Everitt et al., 1983). Seeds were considered germinated when the radicals emerged and the tip of the radicle was uncoiled (Young et al., 1981). The number of germinated seeds was counted daily until $15 \mathrm{~d}$. Non-germinated seeds were tested for viability using a $1 \% \mathrm{w} / \mathrm{v}$ tetrazolium chloride solution (Sbatella and Wilson, 2010). Seed viability was estimated as the percentage of total seeds that germinated plus those tested positive in tetrazolium chloride test.

\subsection{Progeny seedling fitness}

A 50-seed subsample of $K$. scoparia was randomly selected from each plot sample, and sown in germination trays $(53 \mathrm{~cm} \times 35 \mathrm{~cm} \times 15 \mathrm{~cm}$ ) filled with a commercial potting mix (VermiSoil $^{\mathrm{TM}}$, Vermicrop Organics, 4265 Duluth Avenue, Rocklin, CA, USA) in the greenhouse at MSU-SARC. Emerged seedlings were thinned to obtain 10 uniform plants per tray. Treatments were arranged in a completely randomized design with four replications, and experiments were repeated. The greenhouse was maintained at $26 / 23 \pm 3{ }^{\circ} \mathrm{C}$ day/night temperature and $16 / 8 \mathrm{~h}$ photoperiod. Plants were watered daily to avoid moisture stress, and fertilized (Miracle-Gro water-soluble fertilizer [24-8-16], Scotts Miracle-Gro Products Inc., 14111 Scottslawn Road, Marysville, OH, USA) once weekly to maintain good growth. Growth parameters including seedling height, width, and number of primary branches per seedling were recorded $42 \mathrm{~d}$ after planting (DAP). The aboveground biomass from each tray was harvested at 42 DAP, dried at $60{ }^{\circ} \mathrm{C}$ for $3 \mathrm{~d}$, and the average shoot dry weight per seedling was determined.

\subsection{Statistical analyses}

All data were subjected to ANOVA using the MIXED procedure in SAS (Statistical Analysis Systems ${ }^{\circledR}$, version 9.2, SAS Institute Inc., SAS Campus Drive, Cary, NC 27513, USA). Variances were divided into random effects (year or run, replication nested within a year or run, and interactions involving either of these two variables) and fixed effects (herbicide treatment). Data was transformed before analysis to improve the normality of residuals and homogeneity of variance. Data on visually assessed percent control, dry weight (percentage of nontreated), percentage seed reduction, and percent seed viability were arcsine-transformed, and data on progeny seedling height, width, number of primary branches, shoot dry weight, and 100-seed weight were square-root-transformed. Nontransformed means are presented in tables based on the interpretation from the transformed data. Means were separated using Fisher's Protected LSD test at $\mathrm{P}<0.05$.

\section{Results and discussion}

\subsection{K. scoparia control}

K. scoparia densities ranged from 8 to 10 plants $\mathrm{m}^{-2}$ in the postharvest wheat stubble plots in 2012 and 2013. Averaged over years, a single postharvest application of paraquat + atrazine,

Table 2

Visual ratings of Kochia scoparia at 7, 14, and $28 \mathrm{~d}$ after treatment (DAT) of postharvest-applied herbicides in wheat stubble averaged over 2012 and 2013 at the Montana State University, Southern Agricultural Research Center near Huntley, MT, USA.

\begin{tabular}{|c|c|c|c|c|}
\hline \multirow[t]{2}{*}{$\operatorname{Herbicide}(s)^{\mathrm{a}}$} & \multirow{2}{*}{$\frac{\text { Rate(s) }}{\mathrm{kg} \mathrm{ha}^{-1}}$} & 7 DAT & 14 DAT & 28 DAT \\
\hline & & \multicolumn{3}{|c|}{$\%$} \\
\hline Dicamba & 0.56 ae & 18 & 23 & 47 \\
\hline Dicamba $+2,4-D^{c, d}$ & $0.56 \mathrm{ae}+0.56 \mathrm{ae}$ & 21 & 36 & 55 \\
\hline Dicamba + atrazine $^{\mathrm{b}}$ & 0.56 ae +0.56 ai & 47 & 63 & 80 \\
\hline Dicamba + glyphosate $^{\mathrm{d}}$ & $0.56 \mathrm{ae}+1.26 \mathrm{ae}$ & 36 & 86 & 98 \\
\hline $\begin{array}{l}\text { Diflufenzopyr + dicamba } \\
\quad+2,4-\mathrm{D}\end{array}$ & $\begin{array}{l}0.06 \mathrm{ai}+0.15 \text { ae } \\
+0.56 \text { ae }\end{array}$ & 41 & 54 & 67 \\
\hline Glyphosate $^{c}$ & 1.26 ae & 18 & 80 & 97 \\
\hline Glufosinate $^{c}$ & 0.59 ai & 67 & 87 & 95 \\
\hline Paraquat & $0.84 \mathrm{ai}$ & 87 & 95 & 98 \\
\hline Paraquat + atrazine & $0.84 \mathrm{ai}+0.56 \mathrm{ai}$ & 94 & 100 & 100 \\
\hline Paraquat + linuron $^{\mathrm{d}}$ & $0.84 \mathrm{ai}+0.84 \mathrm{ai}$ & 95 & 99 & 100 \\
\hline Paraquat + metribuzin & $0.84 \mathrm{ai}+0.84 \mathrm{ai}$ & 97 & 100 & 100 \\
\hline Saflufenacil + atrazine $e^{\mathrm{b}, \mathrm{c}}$ & $0.05 \mathrm{ai}+0.56 \mathrm{ai}$ & 75 & 87 & 97 \\
\hline Saflufenacil $+2,4-D^{b, c}$ & $0.05 \mathrm{ai}+0.56 \mathrm{ai}$ & 76 & 87 & 96 \\
\hline Tembotrione + atrazine $^{\mathrm{b}}$ & $0.09 \mathrm{ai}+0.56 \mathrm{ai}$ & 37 & 79 & 91 \\
\hline Topramezone + atrazine $^{\mathrm{b}}$ & $0.02 \mathrm{ai}+0.56 \mathrm{ai}$ & 30 & 78 & 93 \\
\hline $\operatorname{LSD}(0.05)$ & - & 5 & 4 & 4 \\
\hline
\end{tabular}

a Herbicide treatments were applied 2-3 wk following the harvest of wheat, at the early bloom stage of 45 - to $50-\mathrm{cm}$-tall $K$. scoparia plants, with an average density of 8-10 plants $\mathrm{m}^{-2}$ in wheat stubble.

b Methylated seed oil (MSO) at $1 \% \mathrm{v} / \mathrm{v}$ was included.

c Ammonium sulfate (AMS) at $2 \% \mathrm{w} / \mathrm{v}$ was included.

d Nonionic surfactant (NIS) at $0.5 \% \mathrm{v} / \mathrm{v}$ was included. 
Table 3

Kochia scoparia plant dry weight and seed reduction with the postharvest-applied herbicides in wheat stubble averaged over 2012 and 2013 at the Montana State University, Southern Agricultural Research Center near Huntley, MT, USA.

\begin{tabular}{|c|c|c|c|}
\hline \multirow[t]{2}{*}{ Herbicide $(s)^{a}$} & \multirow{2}{*}{$\begin{array}{l}\text { Rate (s) } \\
\mathrm{kg} \mathrm{ha}^{-1}\end{array}$} & Dry weight $^{\mathrm{e}}$ & $\begin{array}{l}\text { Seed } \\
\text { reduction }\end{array}$ \\
\hline & & \multicolumn{2}{|c|}{$\%$ of nontreated } \\
\hline Dicamba $^{c, d}$ & 0.56 ae & 64 & 46 \\
\hline Dicamba $+2,4-D^{c, d}$ & 0.56 ae +0.56 ae & 57 & 53 \\
\hline Dicamba + atrazine $^{b}$ & 0.56 ae +0.56 ai & 51 & 78 \\
\hline Dicamba + glyphosate $^{\mathrm{d}}$ & 0.56 ae +1.26 ae & 30 & 100 \\
\hline $\begin{array}{l}\text { Diflufenzopyr } \\
\quad+\text { dicamba }+2,4-\mathrm{D}\end{array}$ & $\begin{array}{l}0.06 \text { ai }+0.15 \text { ae } \\
+0.56 \text { aе }\end{array}$ & 60 & 32 \\
\hline Glyphosate $^{c}$ & 1.26 ae & 31 & 100 \\
\hline Glufosinate $^{c}$ & 0.59 ai & 32 & 100 \\
\hline Paraquat & 0.84 ai & 31 & 100 \\
\hline Paraquat + atrazine & $0.84 \mathrm{ai}+0.56 \mathrm{ai}$ & 29 & 100 \\
\hline Paraquat + linuron $^{\mathrm{d}}$ & $0.84 \mathrm{ai}+0.84 \mathrm{ai}$ & 30 & 100 \\
\hline Paraquat + metribuzin & $0.84 \mathrm{ai}+0.84 \mathrm{ai}$ & 27 & 100 \\
\hline Saflufenacil + atrazine $e^{b, c}$ & $0.05 \mathrm{ai}+0.56 \mathrm{ai}$ & 31 & 100 \\
\hline Saflufenacil $+2,4-D^{b, c}$ & $0.05 \mathrm{ai}+0.56 \mathrm{ai}$ & 28 & 100 \\
\hline Tembotrione + atrazine ${ }^{b}$ & $0.09 \mathrm{ai}+0.56 \mathrm{ai}$ & 32 & 100 \\
\hline Topramezone + atrazine ${ }^{\mathrm{b}}$ & $0.02 \mathrm{ai}+0.56 \mathrm{ai}$ & 31 & 100 \\
\hline $\operatorname{LSD}(0.05)$ & - & 5 & 2.4 \\
\hline
\end{tabular}

a Herbicide treatments were applied $2-3 \mathrm{wk}$ following the harvest of wheat, at the early bloom stage of 45 - to $50-\mathrm{cm}$-tall $K$. scoparia plants in wheat stubble.

b Methylated seed oil (MSO) at $1 \% \mathrm{v} / \mathrm{v}$ was included.

c Ammonium sulfate (AMS) at $2 \% \mathrm{w} / \mathrm{v}$ was included.

d Nonionic surfactant (NIS) at $0.5 \% \mathrm{v} / \mathrm{v}$ was included.

e $K$. scoparia plants were harvested from a $1-\mathrm{m}^{2}$ quadrat placed at the center of each plot. Plant dry weight and seed production averaged $429 \mathrm{~g}$ and 104,100 seeds $\mathrm{m}^{-2}$, respectively, in nontreated plots.

paraquat + linuron, or paraquat + metribuzin at the early bloom stage $(45-50 \mathrm{~cm}$ tall plants) provided complete control of K. scoparia at 28 DAT, and did not differ from paraquat, glyphosate, dicamba + glyphosate, saflufenacil + atrazine, or saflufenacil + 2, 4D treatments (Table 2). Glyphosate activity on K. scoparia was much slower compared to the contact activity of glufosinate, paraquat- or saflufenacil-based treatments, evident from the differences in control ratings at 7 vs. 14 DAT. Also in a greenhouse study, paraquat when tank-mixed with the PS II-inhibitors including atrazine $\left(0.56 \mathrm{~kg} \mathrm{ha}^{-1}\right)$, linuron $\left(0.84 \mathrm{~kg} \mathrm{ha}^{-1}\right)$, or metribuzin $\left(0.42 \mathrm{~kg} \mathrm{ha}^{-1}\right)$ provided complete control of 8 - to $10-\mathrm{cm}$ tall $K$. scoparia plants 7 DAT (Kumar et al., 2014). Control 28 DAT with glufosinate, tembotrione + atrazine, and + topramezone atrazine was 91-95\% (Table 2). Dicamba applied alone was the least effective postharvest herbicide treatment (47\% control at 28 DAT); however, tank-mixing dicamba with atrazine improved $K$. scoparia control (80\% at 28 DAT). Furthermore, the control was higher than dicamba + 2, 4-D (55\% control at 28 DAT) or diflufenzopyr + dicamba $+2,4-\mathrm{D}$ (67\% only at
28 DAT) treatment. Also reported in other broadleaf weed species such as A. palmeri and S. obtusifolia., control from a late-season (early bloom stage of the weed) application of dicamba $\left(0.28 \mathrm{~kg} \mathrm{ha}^{-1}\right)$ or 2 , 4-D (1.06 $\mathrm{kg} \mathrm{ha}^{-1}$ ) did not exceed 70\% (Jha and Norsworthy, 2012; Taylor and Oliver, 1997).

\subsection{Plant dry weight and seed production}

All postharvest herbicide treatments were comparable for K. scoparia biomass reduction, which ranged from 68 to $73 \%$ of the nontreated, except dicamba, dicamba +2 , 4-D, dicamba + atrazine, and diflufenzopyr + dicamba $+2,4$-D treatments (Table 3). Among dicamba-containing treatments, dicamba + atrazine provided greater biomass reduction, although it was $<50 \%$.

All herbicides tested prevented late-season $K$. scoparia seed production when applied at the early bloom stage in the postharvest wheat stubble, except dicamba, dicamba $+2,4-D$, dicamba + atrazine, and diflufenzopyr + dicamba +2 , 4-D (Table 3). Dicamba and dicamba +2 , 4 -D reduced seed production by only 46 and 53\% of the nontreated check (104,100 seeds $\mathrm{m}^{-2}$ ) respectively, which were lower than the $78 \%$ seed reduction by dicamba + atrazine. Diflufenzopyr + dicamba +2 , 4-D was the least effective treatment in reducing late-season $K$. scoparia seed production. Consistent with our results, Mickelson et al. (2004) reported that a late-season application of paraquat $\left(0.701 \mathrm{~kg} \mathrm{ha}^{-1}\right)$ and glyphosate $\left(0.631 \mathrm{~kg} \mathrm{ha}^{-1}\right)$ reduced $K$. scoparia seed production by $97-99 \%$. Similarly, up to $99 \%$ reduction in seed production of S. obtusifolia, A. theophrasti Medik., Ipomoea lacunosa L., and Sida spinosa L. has been reported with glyphosate, applied even at lower rates of $0.42-0.84 \mathrm{~kg} \mathrm{ha}^{-1}$ at early flowering to early seed-set stage of the weeds (Biniak and Aldrich, 1986; Clay and Griffin, 2000; Thomas et al., 2005; Walker and Oliver, 2008). Although dicamba $\left(0.280 \mathrm{~kg} \mathrm{ha}^{-1}\right)$ and 2, 4-D (1.06 kg ha-1) applied at the first visible sign of inflorescence reduced seed production of A. palmeri plants by 75 and $84 \%$, respectively (Jha and Norsworthy, 2012), the herbicides were not effective in reducing late-season $K$. scoparia seed bank additions in the postharvest wheat stubble.

\subsection{Hundred seed weight and seed viability}

The data shown in Table 4 represents only those treatments in which $K$. scoparia survivors did produce seed following a postharvest herbicide application in wheat stubble, and the nontreated check. Dicamba alone, dicamba +2 , 4-D, and diflufenzopyr + dicamba +2 , 4-D treatments applied at the early bloom stage of $K$. scoparia did not influence the 100 -seed weight compared to the nontreated check (Table 4). Also reported in other weed species, such as A. palmeri, dicamba $\left(0.28 \mathrm{~kg} \mathrm{ha}^{-1}\right)$ applied at the early inflorescence stage had

Table 4

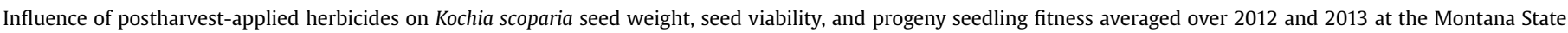
University, Southern Agricultural Research Center near Huntley, MT, USA.

\begin{tabular}{|c|c|c|c|c|c|c|c|}
\hline \multirow[t]{2}{*}{ Herbicide $(s)^{a}$} & Rate(s) & 100-seed weight & Seed viability $^{\mathrm{b}}$ & Seedling height ${ }^{\mathrm{c}}$ & Seedling width ${ }^{c}$ & Primary branches ${ }^{c}$ & Shoot dry weight ${ }^{c}$ \\
\hline & $\mathrm{kg} \mathrm{ha}^{-1}$ & $\mathrm{mg}$ & $\%$ & $\mathrm{~cm}$ & $\mathrm{~cm}$ & No. seedling ${ }^{-1}$ & g seedling $^{-1}$ \\
\hline Dicamba & 0.56 ae & 130 & 92 & 34.7 & 17.5 & 16 & 2.6 \\
\hline Dicamba $+2,4-\mathrm{D}$ & 0.56 ae +0.56 ae & 116 & 91 & 38.1 & 21.5 & 17 & 3.2 \\
\hline Dicamba + atrazine & 0.56 ae +0.56 ai & 100 & 84 & 37.5 & 19.8 & 17 & 2.9 \\
\hline $\begin{array}{l}\text { Diflufenzopyr + dicamba } \\
\quad+2,4-\mathrm{D}\end{array}$ & $\begin{array}{l}0.06 \mathrm{ai}+0.15 \mathrm{ae} \\
+0.56 \mathrm{ae}\end{array}$ & 117 & 92 & 34.7 & 17.6 & 17 & 2.6 \\
\hline Nontreated & - & 130 & 92 & 37.2 & 19.2 & 16 & 2.8 \\
\hline $\operatorname{LSD}(0.05)$ & - & 21 & 6 & NS & NS & NS & NS \\
\hline
\end{tabular}

${ }^{\text {a }}$ Herbicide treatments were applied 2-3 wk following the harvest of wheat, at the early bloom stage of 45- to 50-cm-tall $K$. scoparia plants in wheat stubble. Only those treatments in which $K$. scoparia survivors produced seed following a postharvest herbicide application in wheat stubble, and the nontreated check are included.

b Seed viability was determined as the percentage of total seeds that germinated plus those tested positive in tetrazolium chloride test.

c Progeny growth parameters were recorded at $42 \mathrm{~d}$ after planting in a greenhouse. 
no effect on the 100-seed weight of the treated plants (Jha and Norsworthy, 2012). However, addition of atrazine to dicamba reduced the 100 -seed weight of treated plants, which was $100 \mathrm{mg}$ compared to $130 \mathrm{mg}$ for the nontreated check (Table 4). Seed weight is an indicator of seedling vigor (Steadman et al., 2006).

Furthermore, dicamba + atrazine reduced viability of $K$. scoparia seeds produced by the treated plants compared to the nontreated (Table 4). None of the other dicamba-containing treatments affected seed viability. The reduction in seed viability may be due to the abscission of floral structures or inhibition of seed development causing immature embryos or dead seeds (Isaacs et al., 1989; Steadman et al., 2006). Our results indicate a possible negative effect of atrazine on seed viability and seedling vigor of $K$. scoparia plants treated at the early bloom stage.

\subsection{Progeny seedling fitness}

The data shown in Table 4 represents only those treatments in which $K$. scoparia survivors did produce seed following a postharvest herbicide application in wheat stubble, and the nontreated check. Growth attributes including height, width, number of primary branches, and shoot dry weight of progeny seedlings of $K$. scoparia did not differ among the dicamba-containing postharvest-applied herbicides at 42 DAP (Table 4), and averaged $36.4 \mathrm{~cm}, 19.1 \mathrm{~cm}, 17$, and $2.8 \mathrm{~g} \mathrm{plant}^{-1}$, respectively. The results confirm that a late-season (early bloom stage) application of dicamba or 2, 4-D in postharvest wheat stubble will have minimal influence on the competitive ability of $K$. scoparia seedlings (obtained from the treated plants) in the following season.

\section{Conclusions}

In summary, a single application of paraquat alone or tankmixed with atrazine/linuron/metribuzin, saflufenacil + atrazine, saflufenacil $+2,4-\mathrm{D}$, glyphosate alone or tank-mixed with dicamba, glufosinate, tembotrione + atrazine, or topramezone + atrazine at the early bloom stage of $K$. scoparia prevented late-season seed rain and seed bank additions in postharvest wheat stubble. The "zero seed tolerance" approach is one of the best management practices (BMPs) for the containment of herbicide resistance (Norsworthy et al., 2012). This strategy becomes more imperative for a species like K. scoparia, with prolific seed production (Stallings et al., 1995) and rapid seed bank turnover (due to low dormancy and high seedling recruitment) (Dille et al., 2012). A late-season application of dicamba alone or tank-mixed with 2, 4-D and/or diflufenzopyr was not effective in controlling $K$. scoparia in postharvest wheat stubble. Nevertheless, dicamba when tank-mixed with atrazine reduced seed production, seed weight and seed viability of treated plants, which would be an additional tool to manage $K$. scoparia infestation in the subsequent corn/grain sorghum crop.

Late-season weed escapes often have limited influence on crop yield (Zimdahl, 2004). Also, growers have to incur additional costs to use late-season (postharvest) herbicides. However, growers need to be educated that besides reducing $K$. scoparia infestation in the following season/crop, preventing late-season seed bank inputs is crucial for the containment of glyphosate and multiple herbicide (glyphosate and ALS-inhibitor)-resistant populations of the weed, which continue to spread and impact larger acreages in the wheatbased cropping systems of the US Great Plains. Growers should proactively utilize the effective late-season (early bloom stage) herbicide programs evaluated in this research to prevent potentially high late-season seed bank increase of $K$. scoparia in wheat stubble ( $>100,000$ seeds $\mathrm{m}^{-2}$ produced by nontreated plants in this study). Additionally, they should pay attention to the recommended usage of these tested postharvest herbicides in wheat stubble to avoid crop injury concerns in the rotational crop (corn/ grain sorghum, soyabean, chemical-fallow), and integrate nonchemical weed control tactics to mitigate the occurrence of any new or multiple herbicide-resistant $K$. scoparia strain on their farm fields.

\section{Acknowledgments}

The authors thank Mr. Nicholas Reichard and Mr. Shane Leland for their technical assistance in this research. Funding obtained from Monsanto Company and Montana Wheat and Barley Committee to conduct this research is gratefully acknowledged.

\section{References}

Al-Ahmadi, M.J., Kafi, M., 2007. Cardinal temperatures for germination of Kochia scoparia (L.). J. Arid Environ. 68, 308-314.

Anderson, R.L., Nielsen, D.C., 1996. Emergence pattern of five weeds in the central Great Plains. Weed Technol. 10, 744-749.

Bagavathiannan, M.V., Norsworthy, J.K., 2012. Late-season seed production in arable weed communities: management implications. Weed Sci. 60, 325-334.

Baker, D.V., Withrow, J.R., Brown, C.S., Beck, K.G., 2010. Tumbling: use of diffuse knapweed (Centaurea diffusa) to examine an understudied dispersal mechanism. Invasive Plant Sci. Manag. 3, 301-309.

Beckie, H.J., Blackshaw, R.E., Low, R., Hall, L.M., Sauder, C.A., Martin, S., Brandt, E.N., Shirriff, S.W., 2013. Glyphosate- and acetolactate synthase inhibitor-resistant kochia (Kochia scoparia) in western Canada. Weed Sci. 61, 310-318.

Bennett, A.C., Shaw, D.R., 2000. Effect of preharvest desiccants on weed seed production and viability. Weed Technol. 14, 530-538.

Biniak, B.M., Aldrich, R.J., 1986. Reducing velvetleaf (Abutilon theophrasti) and giant foxtail (Setaria faberi) seed production with stimulated-roller herbicide applications. Weed Sci. 34, 256-259.

Christoffoleti, P.J., Westra, P.B., Moore, F., 1997. Growth analysis of sulfonylurearesistant and -susceptible kochia (Kochia scoparia). Weed Sci. 45, 691-695.

Clay, P.A., Griffin, J.L., 2000. Weed seed production and seedling emergence responses to late-season glyphosate applications. Weed Sci. 48, 481-486.

Cranston, H.J., Kern, A.J., Hackett, J.L., Miller, E.K., Maxwell, B.D., Dyer, W.E., 2001. Dicamba resistance in kochia. Weed Sci. 49, 164-170.

Dahl, G.K., Dexter, A.G., Nalewaja, J.D., 1982. Kochia competition and control in wheat. In: North Central Weed Control Conference. Indianapolis, USA.

Dille, J.A., Stahlman, P.W., Geier, P.W., Riffel, J.D., Currie, R.S., Wilson, R.G., Sbatella, G.M., Westra, P., Kniss, A.R., Moechnig, M.J., Cole, R.M., 2012. Kochia emergence profiles across the central Great Plains. In: Weed Science Society of America Conference. Hawaii, USA.

Durgan, B.R., Dexter, A.G., Miller, S.D., 1990. Kochia (Kochia scoparia) interference in sunflower (Helianthus annus). Weed Technol. 4, 52-56.

Eberlein, C.V., Fore, Z.A., 1984. Kochia biology. Weeds Today 15, 5-6.

Everitt, J.H., Alaniz, M.A., Lee, J.B., 1983. Seed germination characteristics of Kochic scoparia. J. Range Manag. 36, 646-648.

Fawcett, R.S., Slife, F.W., 1978. Effects of 2, 4-D and dalapon on weed seed production and dormancy. Weed Sci. 26, 543-547.

Forcella, F., 1985. Spread of kochia in the northwestern United States. Weeds Today $16,4-6$.

Friesen, L.F., Beckie, H.J., Warwick, S.I., Van Acker, R.C., 2009. The biology of Canadian weeds. 138. Kochia scoparia (L.) Schrad. Can. J. Plant Sci. 89, 141-167.

Heap, I.M., 2014. International Survey of Herbicide Resistant Weeds. www. weedscience.org (accessed October 2014).

Isaacs, M.A., Murdock, E.C., Toler, J.E., Wallace, S.U., 1989. Effects of late-season herbicide applications on sicklepod (Cassia obtusifolia) seed production and viability. Weed Sci. 37, 761-765.

Jacobson, J., Jackson, G., Jones, C., 2005. Fertilizer Guidelines for Montana Crops Montana State University. EB, 161

Jha, P., Norsworthy, J.K., 2012. Influence of late-season herbicide applications on control, fecundity, and progeny fitness of glyphosate-resistant palmer amaranth (Amaranthus palmeri) biotypes from Arkansas. Weed Technol. 26, 807-812.

Kumar, V., Jha, P., Reichard, N., 2014. Occurrence and characterization of kochia (Kochia scoparia) populations with resistance to glyphosate in Montana. Weed Technol. 28, 122-130.

Mickelson, J.A., Bussan, A.J., Davis, E.S., Hulting, A.G., Dyer, W.E., 2004. Postharvest kochia (Kochia scoparia) management with herbicides in small grains. Weed Technol. 18, 426-431.

Mengistu, L.W., Messersmith, C.G., 2002. Genetic diversity of kochia. Weed Sci. 50, 498-503.

Norsworthy, J.K., Ward, S.M., Shaw, D.R., Llewellyn, R.S., Nichols, R.L., Webster, T.M., Bradley, K.W., Frisvold, G., Powles, S.B., Burgos, N.R., Witt, W.W., Barrett, M., 2012. Reducing the risks of herbicide resistance: best management practices and recommendations. Weed Sci. 60, 31-62.

Preston, C., Belles, D.S., Westra, P.H., Nissen, S.J., Ward, S.M., 2009. Inheritance of resistance to the auxinic herbicide dicamba in kochia (Kochia scoparia). Weed Sci. 57, 43-47. 
Primiani, M.M., Cotterman, J.C., Saari, L.L., 1990. Resistance of Kochia scoparia to sulfonylurea and imidazolinone herbicides. Weed Technol. 4, 169-172.

Sbatella, G.M., Wilson, R.G., 2010. Isoxaflutole shifts kochia (Kochia scoparia) populations in continuous corn. Weed Technol. 24, 392-396.

Schwinghamer, T.D., Van Acker, R.C., 2008. Emergence timing and persistence of kochia (Kochia Scoparia). Weed Sci. 56, 37-41.

Stallings, G.P., Thill, D.C., Mallory-Smith, C.A., Shafii, B., 1995. Pollen-mediated gene flow of sulfonylurea-resistant kochia (Kochia scoparia). Weed Sci. 43, 95-102.

Steadman, K.J., Eaton, D.M., Plummer, J.A., Ferris, D.J., Powles, S.B., 2006. Late-season non-selective herbicide applications reduce Lolium rigidum seed numbers, seed viability, and seedling fitness. Aust. J. Agric. Res. 57, 133-141.

Taylor, S.E., Oliver, L.R., 1997. Sicklepod (Senna obtusifolia) seed production and viability as influenced by late-season postemergence herbicide applications. Weed Sci. 45, 497-501.

Thomas, W.E., Pline-Srnic, W.P., Viator, R.A., Wilcut, J.W., 2005. Effects of glyphosate application timing and rate on sicklepod (Senna obtusifolia) fecundity. Weed Technol. 19, 55-61.
Waite, J., Thompson, C.R., Peterson, D.E., Currie, R.S., Olson, B.L.S., Stahlman, P.W., Khatib, K.A., 2013. Differential kochia (Kochia scoparia) populations response to glyphosate. Weed Sci. 61, 193-200.

Walker, E.R., Oliver, L.R., 2008. Weed seed production as influenced by glyphosate applications at flowering across a weed complex. Weed Technol. 22, 318-325.

Weatherspoon, D.M., Schweizer, E.E., 1971. Competition between sugarbeets and five densities of kochia. Weed Sci. 19, 125-128.

Wicks, G.A., Martin, A.R., Mahnken, G.W., 1993. Control of triazine-resistant kochia (Kochia scoparia) in conservation tillage corn (Zea mays). Weed Sci. 41, 225-231.

Wicks, G.A., Martin, A.R., Haack, A.E., Mahnken, G.W., 1994. Control of triazineresistant kochia (Kochia scoparia) in sorghum (Sorghum bicolor). Weed Technol. 8, 748-753.

Young, J.A., Evans, R.A., Stevens, R., Everett, R.L., 1981. Germination of Kochia prostrata seed. Agron. J. 73, 957-961.

Zimdahl, R.L., 2004. Weed-Crop Competition. A Review, second ed. Blackwell Publishing Ltd., Oxford, UK, p. 220. 